\title{
CERTAINTY AND ASCERTAINABILITY OF CRIMINAL LAW AFTER THE PITCAIRN TRIALS
}

\author{
Fran Wright
}

\begin{abstract}
According to the certainty principle, someone should not be charged with or convicted of a criminal offence that they did not and could not have known existed. This article considers this principle in light of the trial of seven Pitcairn Islanders for offences under the English Sexual Offences Act 1956. The islanders were unaware of the terms of the Act and had very limited access to information about criminal law. Their claim that the prosecutions were an abuse of process failed because they had indirect access to legal advice and also must have known that their conduct was criminal.
\end{abstract}

The article argues that the reasons given for upholding the convictions were inadequate. Criminal law on Pitcairn was uncertain. However, uncertain law is not always unenforceable. Courts have to balance the interests of defendants with those of victims. Certainty is an important principle but it is not a rigid and inflexible requirement. Case law suggests that there is a defence based on uncertainty only if the existence of an offence was not predictable and the offence lacks a fault element. In other cases, a defendant can be said to have fair notice and is not at risk of being convicted in the absence of subjective fault.

\section{INTRODUCTION}

It is conventional legal wisdom that a person should not be charged with or convicted of a criminal offence that they did not and could not have known existed at the time when they allegedly committed it. This is known as the "certainty principle". The justification usually given for this requirement is that, without it, people cannot plan their lives in order to avoid criminal liability.

This article examines the application of this principle in the recent trials of seven Pitcairn islanders for offences under the English Sexual Offences Act 1956 (hereafter SOA). ${ }^{1}$ It considers

* BA (Hons) (Stirling), LLB (Auckland), LLM (Victoria University of Wellington). Lecturer in Law at Bradford University Law School, Bradford, UK. My thanks to Geoff McLay, Jess Guth, Myfanwy Trueman and an anonymous reviewer for their help and encouragement in refining this article. I would also like to thank Tony Angelo for igniting my interest in Pitcairn, although of course responsibility for its content is entirely my own. 
just one aspect of the case, the islanders' argument that the proceedings against them were an abuse of process. ${ }^{2}$ One of the reasons given by the Pitcairn defendants was that the law relating to sexual offences was uncertain, so that the trial was unfair and contrary to the public interest. ${ }^{3}$ They argued that it was unclear whether Britain had jurisdiction over Pitcairn at all, and if it did, it was unclear which aspects of Pitcairn life were governed by local and which by English law. If English law applied to rape and indecent assault, the details were unascertainable because there were no copies of British statutes or textbooks on the island and no residents of the island had legal training. This argument was unsuccessful and six islanders were convicted. A series of courts, ending with the Privy Council, agreed that the convictions were legitimate. ${ }^{4}$ All held that the SOA was part of Pitcairn law at the time when the offending occurred and that the content of the law was certain. Some judges considered access to legal advice satisfactory; others doubted this but held that the islanders still knew enough for their convictions to be fair.

This article argues that the law relating to sexual offending on Pitcairn was uncertain, and the way in which islanders could access legal advice was unsatisfactory. However, the courts were probably correct to uphold the convictions, albeit they did so for the wrong reasons. Uncertainty by itself is not sufficient to make an offence unenforceable or to make a conviction an abuse of process. It is argued in this article that uncertainty will only result in unenforceability where it meant that the defendant did not have fair notice of the existence of an offence and where that offence lacks a subjective fault requirement, so that conviction without blame is possible. These criteria are consistent with most accounts of the reasons why criminal law must be certain, and they were satisfied in the Pitcairn case. There are some aspects of this "modified" certainty test that could be

1 This statute has now been replaced by the Sexual Offences Act 2003 but none of the offending came under the newer statute.

2 There are two broad grounds for a stay of proceedings on grounds of an abuse process: that a fair trial is not possible, and that "it would be contrary to the public interest in the integrity of the criminal justice system that a trial should take place." The remedy is discretionary. $R v$ Latif [1996] 1 WLR 104, 112 (HL), Lord Steyn.

3 For a detailed account of other aspects of the trials, see Sue Farran "The Case of Pitcairn: A Small Island, Many Questions" (2007) 11 Journal of South Pacific Law 124 and Stephen Guest "Law, Legality and Reciprocity on Pitcairn" in Dawn Oliver (ed), The Pitcairn Island case, Oxford University Press (forthcoming) currently available at http://www.ucl.ac.uk/ uctlsfd/papers/Legality,\%20reciprocity\%20a nd\%20the\%20criminal\%20law\%20on\%20Pitcairn.rtf) (accessed 30 March 2009).

$4 \quad R v$ Christian (Pitcairn Islands Supreme Court (PISC), 24 May 2005, T37-46/2003), $R v$ Christian (Pitcairn Islands Court of Appeal (PICA)) [2006] 4 LRC 746, $R v$ Christian [2007] AC 400 (PC). This article will not consider whether an application for a stay of proceedings on the basis of an abuse of process was the most appropriate mechanism for raising the issue of uncertainty. The principles governing uncertainty are the same whether an argument is structured in terms of a defence of reasonable ignorance of the law, a breach of human rights legislation or abuse of process and for current purposes there is no need to distinguish between these approaches. 
criticised, but the arguments in favour of a more fact-sensitive approach are stronger than the arguments in favour of a rigid certainty rule.

\section{THE CERTAINTY PRINCIPLE AND THE NEED FOR CRIMINAL LAW TO BE ASCERTAINABLE}

Certainty of criminal law is a requirement under the International Covenant on Civil and Political Rights. Article 15(1) provides:

No one shall be held guilty of any criminal offence on account of any act or omission which did not constitute a criminal offence, under national or international law, at the time when it was committed. Nor shall a heavier penalty be imposed than the one that was applicable at the time when the criminal offence was committed...

Both jurisdictions involved with the Pitcairn case, the United Kingdom and New Zealand, have incorporated a version of this principle into their domestic law. ${ }^{5}$

Criminal law may be uncertain in a number of ways. The most obvious situation in which there is uncertainty is where an offence has been created (or altered) retrospectively. ${ }^{6}$ Other situations where there is uncertainty include those where a law has not been publicised (unascertainability), and where it is impossible to ascertain with certainty what the elements of a particular offence are.

It is one thing to say that criminal law ought to be "certain" but that presupposes that certainty is a clear concept in itself. Certainty is in fact a question of degree: is a criminal offence certain only if every person knows its terms and the penalty for a breach? Is it sufficient to know that such an offence exists? Or simply to know that it is "probably" criminal to do some things? There is no definition of certainty or indication of how much certainty is needed in the legislation and

5 Under the Crimes Act 1961, s10A "Notwithstanding any other enactment or rule of law to the contrary, no person shall be liable in any criminal proceedings in respect of an act or omission by him if, at the time of the act or omission, the act or omission by him did not constitute an offence." Section 26 (1) of the New Zealand Bill of Rights Act 1990 states, "[n]o one shall be liable to conviction of any offence on account of any act or omission which did not constitute an offence by such person under the law of New Zealand at the time it occurred." For a discussion of the differences between these, see Paul Rishworth, Grant Huscroft, Scott Optican \& Richard Mahoney The New Zealand Bill of Rights (Oxford University Press, Melbourne, 2003) 708-709.

The equivalent section in the European Convention of Human Rights is Article 7 (1): "No one shall be held guilty of any criminal offence on account of any act or omission which did not constitute a criminal offence under national or international law at the time when it was committed. Nor shall a heavier penalty be imposed than the one that was applicable at the time the criminal offence was committed." This is incorporated into English law through the Human Rights Act 1998.

6 Cases of actual retrospectivity tend to involve common law rather than statutory offences, but this does not mean that the issue cannot arise where criminal law is codified. Even codified criminal law requires interpretation and wherever the interpretation of a provision changes, the prospect of retrospectivity is there. 
conventions that require it, but a rough sense of what it involves may be found by looking at the reasons why certainty is an important feature of criminal law.

It is not necessary to labour the point that it is unjust to punish someone for breaking a rule that they did not and could not have known existed. Nor is there any doubt that that a government that fails to promulgate its criminal law is itself an unjust government because of its arbitrariness. From a utilitarian perspective, uncertain laws do not achieve their objective as they cannot guide human behaviour. ${ }^{7}$ Lord Diplock put it like this: ${ }^{8}$

The acceptance of the rule of law as a constitutional principle requires that a citizen, before committing himself to any course of action, should be able to know in advance what are the legal consequences that will flow from it.

Some writers link certainty with the very nature of law. ${ }^{9}$ According to Summers, ${ }^{10}$

A rule that is quite unclear in its meaning, for example, is not really law-like. A secret law that is not made public is not really law-like... In all such instances, not only is the efficacy of law sacrificed; the very conceptual claim that this use of first order law is a fully law-like use of law is also at risk and may even have to be forfeited.

Rawls argues that the rule that there is no offence without a law is "implicit in the notion of regulating behavior by public rules. For if, say, statutes are not clear in what they enjoin and forbid, the citizen does not know how he is to behave". ${ }^{11}$

7 The pointlessness of unknowable laws is illustrated by Lim Chin Aik $v$ R [1963] AC 160 (PC). The appellant had been ordered to leave Singapore but had not done so. He was unaware that the order had been made, which was not surprising since it had not been publicised or brought to his attention. The prosecution asserted that this did not affect the appellant's liability because the offence had no mental element, ie, was a strict liability offence. In reaching the conclusion that the legislature could not have intended to create a strict liability offence, the Privy Council took into account that "one of the objects of the Ordinance is the expulsion of prohibited persons from Singapore, but there is nothing that a man can do about it if, before the commission of the offence, there is no practical or sensible way in which he can ascertain whether he is a prohibited person or not" (at 175, per Lord Evershed). Strict liability would therefore serve no purpose: "there must be something he can do, directly or indirectly... which will promote the observance of the regulations. Unless this is so, there is no reason in penalising him, and it cannot be inferred that the legislature imposed strict liability merely in order to find a luckless victim" (at 174 per Lord Evershed).

8 Black-Clawson International Ltd v Papierwerke Waldhof-Aschaffenberg AG [1975] AC 591, 638 (HL) Lord Diplock.

9 See in particular Lon Fuller The Morality of Law (revised ed, Yale University Press, 1969). For a detailed discussion of the debate on this issue, see Leighton McDonald "Positivism and the Formal Rule of Law: Questioning the Connection" (2001) 26 Australian Journal of Legal Philosophy 93, 93.

10 Robert Summers "The Principles of the Rule of Law" (1998-1999) 74 Notre Dame Law Review 1691, 1700.

11 John Rawls A Theory of Justice (Oxford University Press, Oxford, 1999) 238. 
Although the International Convention and provisions in domestic law are in absolute terms, theoretical writing on certainty and the rule of law allows for some flexibility. For Rawls, certainty is an ideal rather than an absolute requirement. Occasional deviations can be tolerated but routine deviations cast doubt on whether there is a justice system at all. ${ }^{12}$ Fuller puts the need for certainty on a sliding scale, varying according to the particular rule in issue. On publication, he accepts that "[i]t would ... be foolish to try and educate every citizen into the full meaning of every law that might conceivably be applied to him ... The need for this education will ... depend upon how far the requirements of law depart from generally shared views of right and wrong". ${ }^{13}$ Ashworth, writing about English criminal law, acknowledges that there is a gap between theory and practice: ${ }^{14}$

It may seem obvious to state that [the courts] should not invent crimes and then punish people for conduct which falls within the new definition. But how would the common law have developed if such a power had not been exercised? The courts have developed and extended English criminal law over the years, untrammelled by the non-retroactivity principle. To 'adapt' the law is a great temptation for a court confronted with a defendant whose conduct it regards as plainly wicked but for which existing offences do not provide.

If the only reason for requiring certainty is efficiency and prevention of injustice in individual cases, then a degree of uncertainty in the content of criminal law should be tolerable provided it does not result in inefficiency or injustice. If certainty has a further purpose, then the absence of inefficiency and injustice by itself will not answer the objection to uncertain or retrospective legislation. What is unclear is what else such a theoretical account would require. As this brief survey of the theoretical literature has shown, even writers who argue for certainty as an intrinsic feature of "law" do not demand complete certainty or knowability. The basic problem remains the same, therefore: given that certainty is a matter of degree, where should the line between sufficiently certain law and uncertain law be drawn? This is the issue that will be explored in the remainder of this article.

\section{THE PITCAIRN PROBLEM}

Pitcairn Island has been occupied since 1790 when it was settled by the surviving Bounty mutineers, accompanied by a number of Tahitian men and women. Britain claimed control in $1898,{ }^{15}$ and some basic administrative mechanisms were put in place. In 1952, provision was made for the Governor of Fiji to also be Governor of the Pitcairn Islands and the Governor obtained some

12 Rawls, above n 11, 238.

13 Fuller, above n 9, 49.

14 Andrew Ashworth Principles of Criminal Law (4 ed, Oxford University Press, Oxford, 2003) 70.

15 By virtue of article 6(2) of the Pacific Order in Council, made under the British Settlements Act 1887. See $R$ $v$ Christian (PC), above n 4, paras 3-4. 
legislative powers. In 1970, when Fiji obtained its own independence, the Pitcairn Ordinance of 1970 repealed the 1952 Ordinance, and a Governor was appointed specifically for the Pitcairn Islands.

From the time when Pitcairn became a British settlement, English law was applied to the island. Article 20 of the 1898 Ordinance provided that "the civil and criminal jurisdiction exerciseable under this Order shall, so far as circumstances admit, be exercised upon the principles of and in conformity with the substance of the law for the time being in force in and for England" (emphasis added). There was specific reference to incorporation of criminal law in article $23:^{16}$

Crimes, offences, wrongs, and breaches of contract against or affecting the person, property, or rights of natives or foreigners, committed by persons subject to this Order, are, subject to the provisions of this Order, punishable or otherwise cognizable, in the same manner as if they were committed against or affected the person, property, or rights of British subjects.

This formula was repeated in the 1952 and 1970 Ordinances. What it meant was any given English statutory provision or common law rule applied in Pitcairn unless it was specifically excluded by the Governor, either directly or because there was a local statute in place. ${ }^{17}$ The theory was probably that the Governor would decide which English law to adopt and then legislate to fill gaps. In practice, all English laws of general application were extended to Pitcairn unless superseded by local legislation. ${ }^{18}$

In practice English law and colonial administration were not in very much evidence. Most of the time Pitcairn was left to its own devices. The island had no lawyers, and there were no copies of English primary or secondary legal sources on the island. The main source of law "on the ground" was the local ordinances. Although there was legislation setting up a court system, prior to the early 2000s, no judges had ever been appointed and no lawyers had been admitted to the Pitcairn bar. Prosecutions even at the magistrates court level were very rare indeed. Pitcairn's Acting Governor in 2000 explained: ${ }^{19}$

16 This wording suggests that offences punishable only with a fine would not be incorporated into Pitcairn law; this is not discussed in any of the decisions in the Christian case, as it was not an issue.

17 For a more detailed discussion of this point see $R v$ Christian (PICA), above n 4, paras 16-29.

18 For a discussion of what "general application" means, see Tony Angelo and Fran Wright "Pitcairn: Sunset on the Empire" [2004] NZLJ 431.

19 Quoted in $R v$ Christian (PC), above $\mathrm{n}$ 4, para 74, Lord Hope. The fact that little was done in reality to uphold the law was not, it should be emphasised, necessarily the result of maladministration or the consequence of colonial neglect. Pitcairn is a small community, where everyone is related. Everyone relies on everyone else, and anonymity is difficult if not impossible. An accuser would have to continue living alongside the accused. Dea Birkett, who visited Pitcairn a few years before the prosecutions in Christian, was told that a man who had committed a serious offence had not been charged because even the police officer feared retribution (Dea Birkett Serpent in Paradise (Anchor Books, New York, 1997) 282). 
There is no civil authority on the island. Governors, Deputy-Governors and Commissioners reside 3000 miles away in New Zealand, visit irregularly and for short periods of a few days only. The schoolteacher (from New Zealand) doubles as the Government Adviser. But is not viewed by the islanders as being in a position of real authority. We rely on a local Police Officer - who is related to every member of the community they serve - to uphold the law ...

In retrospect this was a recipe for disaster. If a culture of offending developed, there was little that could be done about it. Unfortunately, as later events showed, this does appear to be what happened.

Law and order on Pitcairn finally came under scrutiny in the late 1990s. A rape complaint brought by a visitor to the island highlighted the confused state of the law on sexual offending. There was an overlap between the underage sexual connection offences in the SOA and a local offence, which carried a much lower penalty. ${ }^{20}$ Pitcairn's legal adviser "thought it fair to assume that the offender was unaware of the terms of these provisions of the 1956 Act and of the very substantial penalties attaching to them. Furthermore no United Kingdom statutes were available to the public on Pitcairn". ${ }^{21}$ The authorities decided not to prosecute although a formal warning (caution) was given. There was, however, concern that this incident was not an isolated one and in 1997 a police officer from Kent was sent to Pitcairn; this was the first time a United Kingdom police officer had ever visited the island. She investigated a series of allegations of serious sexual assaults. The victims had been aged between 5 and 18 at the time of the offending and the perpetrators ranged in age from 13 to 46 . Some complaints dated back to the 1960 s, others were more recent. ${ }^{22}$ The alleged offenders were a large proportion of the male population of the island, including the Mayor. The victims were a substantial proportion of the female population. This time, the decision was to prosecute. The legal adviser viewed this situation differently from before: "the public interest required that such serious offences against the person should be detected and punished, even though the destruction that might result within the tiny island community seemed incalculable". ${ }^{23}$

20 See discussion below of section 88 of the Justice Ordinance 1966.

21 See discussion in $R v$ Christian (PC), above $\mathrm{n} 4$, paras 50-51, Lord Hope.

$22 R \vee$ Christian (PICA) above n 4, para 113, Judgment of the Court. Also in 1999, a visitor to the island, Ricky Quinn was charged and convicted of unlawful carnal knowledge with a girl of 15 . He was sentenced to 100 days jail, but was allowed to leave the island without serving the sentence. This was a different situation from the 1996 case, because the prosecution was under a local statute, but it also presented difficulties. It was widely believed on the island that the age of consent was 15 years; the prosecution assumed that the English law setting the age of consent applied. It appears that Quinn was later pardoned, but the details are sketchy: "Pitcairn Islanders Fail to Stop Sex Trials" www.theage.com.au/articles (last accessed 5 August 2008).

$23 R v$ Christian (PC), above $\mathrm{n} 4$, para 73, Lord Hope. 
In the autumn of 2004 seven men went on trial in Adamstown, the capital of Pitcairn. ${ }^{24}$ Six were convicted of rape and indecent assault offences under sections 1 and 14 of the SOA. ${ }^{25}$ In his summary of the factual background to the case, Lord Hope emphasised certain features of the offending: the charges covered a period of more than 38 years, and many victims were raped or sexually assaulted repeatedly by the same man. ${ }^{26}$ The offences all involved non-consensual and often physically forcible sexual contact. So far as can be discovered from the courts' decisions, there was no suggestion of consent or of an honest (let alone reasonable) belief in consent. ${ }^{27}$ Dave Brown pleaded guilty to three charges of indecent assault and was convicted of another six. One charge involved "putting his hands down the front of [the victim's] bikini bottom when they were out spearfishing and rubbing her genitals briefly. She was aged 15 at the time and [Dave Brown] was in his early thirties". ${ }^{28}$ Len Brown was convicted of two counts of rape between 1969 and 1972: the victim had been around 18 and Len Brown was in his mid forties. On both occasions he pushed her to the ground and removed her clothes. She did not resist; he was "a tall, strong, fit man" and she was frightened. Again there was no defence based on consent. One of the complainants against Terry Brown was 12 when he first indecently assaulted her. She lived with his family and was treated as his sister. He started by touching her genitals whenever they went to collect firewood and

24 The complainants gave their evidence by video link from Auckland.

251 Rape of woman or man

(1) It is an offence for a man to rape a woman or another man.

(2) A man commits rape if-

(a) he has sexual intercourse with a person (whether vaginal or anal) who at the time of the intercourse does not consent to it; and

(b) at the time he knows that the person does not consent to the intercourse or is reckless as to whether that person consents to it.

14 Indecent assault on a woman

(1) It is an offence, subject to the exception mentioned in subsection (3) of this section, for a person to make an indecent assault on a woman.

(2) A girl under the age of sixteen cannot in law give any consent which would prevent an act being an assault for the purposes of this section.

The details of the interpretation of these sections was not in issue in $R v$ Christian.

$26 R v$ Christian (PC), above $\mathrm{n} 4$, para 55, Lord Hope.

27 The precise details of the offence were not the same throughout the period of the offending on Pitcairn. However, on the facts presented in the Supreme Court, all the charges satisfied the definition of rape under the SOA on all the relevant dates.

$28 R v$ Christian (PISC), above n 4, para 26, Blackie CJ, Johnson \& Lovell-Smith JJ. 
progressed to rape. "He used force and would prise her legs apart. He told her not to tell anybody about his actions". ${ }^{29}$ This continued until she left the island when she was nearly 16.

The decision to prosecute and the subsequent convictions were challenged on multiple grounds. ${ }^{30}$ One group of arguments challenged the decision to bring the prosecutions under the SOA: the defendants argued that English law did not apply at all because Pitcairn had never become a British possession, or alternatively, even if some English statutes applied, this one did not. The second group of arguments was that the prosecutions were an abuse of process. This was a multifaceted attack. Some aspects related to the "late constitution" of Pitcairn's criminal justice system. As noted above, it was only after the process of prosecution had begun that judges and lawyers were appointed from the New Zealand bar, courts established using New Zealand models, rules of evidence enacted, and a prison built. For the purposes of this article, however, the relevant argument related to the islanders' access to and knowledge of the law relating to sexual offences. The defendants argued that they had not known and could not have known that the SOA applied to their conduct and were ignorant of its terms. All these arguments were rejected. Their basis and the reasoning of the courts in rejecting them will be explained below.

\section{A The Incorporation of the Sexual Offences Act 1956 into Pitcairn Law}

There were both general and specific arguments about jurisdiction. The first argument was that Britain had no jurisdiction over Pitcairn. If this had been accepted, the SOA would simply not be law on Pitcairn. The jurisdictional arguments as such are outside the scope of this article but they should be noted because they are also relevant to the argument that Pitcairn law was uncertain. They provide some support for a claim that islanders not only did not but could not reasonably have been expected to know with any precision what law applied to sexual offending.

The general jurisdictional argument was rejected. There was some detailed discussion of the history of Pitcairn and various constitutional documents in the Supreme Court and the Court of Appeal, but the Privy Council declined to consider the matter at all, simply commenting: ${ }^{31}$

$29 R v$ Christian (PISC), above n 4, para 36, Blackie CJ, Johnson \& Lovell-Smith JJ.

30 These arguments emerged at various points in the history of the case, but for present purposes it is not necessary to distinguish between matters that were raised before, during and after the trial as, ultimately, they were all resolved in a single Privy Council decision. Moreover, as the value of particular judgments in terms of precedent is not in issue, the views of the Privy Council will not be treated as more important or worthy of discussion than those of the Pitcairn Supreme Court and Court of Appeal.

$31 R v$ Christian (PC), above $\mathrm{n} 4$, para 10-11, Lord Hoffmann. The approach to the jurisdiction argument found in all the Pitcairn judgments has been criticised for focussing on the "paper trail" and omitting to consider the effect of British neglect of the island or even to interpret the documents before the courts. There is no room here to examine this criticism in detail, and it is not really necessary, as the point of this article is to look at what the Pitcairn judgments tell us about uncertainty and criminal law. In assessing whether the law applicable on Pitcairn was sufficiently certain, the point is that there were some doubts about British authority. See Guest, above n 3, 7. 
Their Lordships declined to investigate this question because it appears to them that the legal status of the island as a British possession is concluded by successive statements of the executive ...For over a hundred years Pitcairn has been administered by the Crown as a British possession and whatever its history or the inclinations of its people may have been, it is unthinkable that the Judicial Committee of the Her Majesty's Privy Council would not accept an executive statement affirming it to be part of the territory of the Crown.

Alternatively, the defendants raised an argument that the SOA itself was not applicable. One reason, they said, was that the formal process by which a British statute was incorporated into Pitcairn law was not followed. This argument relied on section 5 of the Pitcairn Order 1970. This gave the Governor of Pitcairn the power to make laws for "the peace, order and good government of the Islands". Under subsection (3), the Governor was required to publish such laws "in such manner and at such place or places in the Islands as the Governor may from time to time direct". ${ }^{32}$ The SOA had not been published on Pitcairn. This argument was rejected because section 5 applied only to local legislation. In the Privy Council, Lord Hoffmann pointed out, quite reasonably, that the construction of the Pitcairn Order proposed by the defence was impractical and could not have been intended: "[s]ection 14(1) incorporates not only statutes but also the common law and the rules of equity, which hardly admit of 'publication"'. ${ }^{33}$ An argument that the SOA was not a statute of "general application" was also rejected. ${ }^{34}$

There is another possible reason for rejecting the application of the SOA that was not explored in depth. It stemmed from the rule that colonial law applied only if it was consistent with local conditions. If there were both local and colonial offences dealing with particular behaviour, the local offence would replace the colonial offence. The Pitcairn Justice Ordinance 1966 contained a number of sexual offences, including cohabitation by an unmarried couple ${ }^{35}$ and unlawful carnal knowledge: 36

88. Any male person who shall have carnal knowledge of any female child of or over the age of twelve years shall be guilty of an offence and liable to imprisonment for one hundred days.

If this offence covered the same conduct that was covered by the SOA then rape would come under island law, not English law. There is an obvious problem with this interpretation of section

32 Pitcairn Order 1970 (SI 1970/1434).

$33 R v$ Christian (PC) above $\mathrm{n} 4$, para 16, Lord Woolf.

34 For more on this point, see Tony Angelo and Fran Wright "Pitcairn: Sunset on the Empire", above n 18.

35 Section 90 "It shall be an offence for a man and woman to live together as man and wife unless they are legally married and any person found guilty of such offence shall be liable to a fine not exceeding ten dollars." This offence was repealed in 1999 along with the offence of adultery.

36 This ordinance was replaced in 1999 but was in force at the time when all the offending occurred. 
88. The penalty was small and the offence appeared only to apply where the victim was a child. The Justice Ordinance contained no sexual offence involving adult women other than adultery and cohabitation. If sexual offending was covered by local statutes, the offence of rape on Pitcairn was startlingly narrow and left out much conduct that would be regarded as rape in modern society. It was unclear how indecent assaults were to be handled - this would depend on how "carnal knowledge" was interpreted. ${ }^{37}$ No serious consideration was given by the courts to the possibility that there simply was no offence of rape of an adult on the island. The courts concluded that section 88 was to be read in conjunction with the SOA, superseding it only for consensual sexual intercourse with a child aged between 12 and the age of consent. ${ }^{38}$

If the court was correct in concluding that English law was to be incorporated into Pitcairn law, it seems unarguable that the SOA would then apply. However, this does not answer the complaint that the law on rape and indecent assault was uncertain. Uncertainty needs to be assessed from the standpoint of someone asking in, say, 1989 what law applied. The variety of arguments that could be raised to the contrary meant that someone who wished to find out the law of Pitcairn would have difficulty getting a clear answer. There may also have been local interpretations of the offences in the Justice Ordinance that were different from those suggested by the courts. This will not be treated as a stand-alone criticism of the reasoning in the case, but will feed into the critique below of the finding that Pitcairn law was "ascertainable".

\section{B The Ability of Pitcairn Islanders to Discover the Details of Law Relating to Sexual Offending}

The other objection to the enforcement of the SOA was based on the lack of information islanders had about its contents and how it related to the local statute. This relates directly to the element of the certainty principle that requires law to be published or made known to those it affects so that they can use it to regulate their lives. Law can be completely clear and still be inaccessible. On the surface, this argument was a strong one. The Pitcairn Supreme Court found that "at no time during the currency of the accused's offending was English law itself published on the islands. There was no despatch of statutes, legal texts or such compendium publications as Halsbury's Laws of England. Not until 1997 did a copy of Halsbury's Laws of England (4th edn) arrive on the island". ${ }^{39}$ Nor was it possible for an islander who wanted to discover the law to ask a lawyer, because there were no lawyers on the island. If the Pitcairn islanders were unable to discover the law, should that mean that it was an abuse of process to enforce the SOA?

37 For an interesting summary of the variations, see http://www.ageofconsent.com/definitions.htm (last accessed 18 November 2008).

38 See the affidavits in $R v$ Christian (PISC), above n 4, paras 106-107, Blackie CJ, Johnson \& Lovell-Smith JJ.

$39 R v$ Christian (PISC), above n 4, para 95, Blackie CJ, Johnson \& Lovell-Smith JJ. 
There are two main judicial approaches to this point. One denies that ascertainability was a problem at all because the islanders could have discovered the law (the factual argument). The alternative approach rejects the idea that the law must always be physically accessible or that there must be access to advice. If someone knows that particular conduct - such as forcing a twelve year old to have sexual intercourse against her will - is criminal, then that is enough.

\section{The factual argument that information about criminal law on Pitcairn was accessible}

The starting point for the argument that information about criminal law on Pitcairn was really accessible is that there is no enforceable duty to actively publicise every new criminal offence; given the volume of legislation creating criminal offences, this would be unworkable. Such an obligation would also be inconsistent with the well-established rule that ignorance of the law is no excuse. The requirement is that people have access to enough information to allow them to regulate their lives and stay within the law. ${ }^{40}$ This does not require someone to be able to "work it out for themselves". It is enough that someone with appropriate training and knowledge could do it for them. ${ }^{41}$

For the judges who saw the case in terms of physical accessibility, the question was therefore not whether a copy of the Sexual Offences Act 1956 was available, but whether the islanders had been alerted "that rape, indecent assault and incest are crimes punishable, if committed on the island, under English law". ${ }^{42}$ The courts concluded that the islanders had been aware that English law applied to serious offending. The Supreme Court, whose findings on this point were relied on by the subsequent courts, concluded that islanders had access to the law, in the sense that if they requested assistance, they would receive it: "the British administrators recognised and appreciated that because of Pitcairn's physical isolation and small population, the law significantly affected each individual's life and therefore dealt with even minor matters, such as overhanging coconut trees, if asked to assist". ${ }^{43}$ Affidavits from two prominent islanders were quoted in support. ${ }^{44}$ One said, "[a]ll our legal authority ultimately comes from Britain, and it has always been common sense that British law would cover this Island for anything not dealt with in the Local Ordinances or Regulations". ${ }^{45}$ Another islander said "I remember a provision in the Ordinances that English law

$40 R v$ Christian (PICA) above $\mathrm{n} 4$, para 108, Judgment of the Court.

41 Blackpool Corporation v Locker [1948] 1 KB 349, 361 (CA), Scott LJ for the Court.

$42 R v$ Christian (PISC), above n 4, para 96, Blackie CJ, Johnson and Lovell-Smith JJ.

$43 \quad R v$ Christian (PISC), ibid, para 147.

44 These affidavits were from islanders who were not among the accused, although they were related to islanders who were on trial.

$45 R v$ Christian (PISC), above n 4, para 106, Blackie CJ, Johnson and Lovell-Smith JJ. 
applies here if no local law applies, and I would always have expected serious offending, including murder, rape, and serious sexual offending, to have been prosecuted under English law". 46

This level of knowledge was regarded as adequate to satisfy a fair warning requirement. Islanders knew that sexual offending would be punished, and that was enough: ${ }^{47}$

[I]n order to meet the requirements of the rule of law with regard to promulgation, governments must ensure adequate publication of the fact that law which applies to citizens exists, so that those citizens are able to know the law by accessing its content should they wish to. This interpretation ... is the only one compatible with the fundamental legal principle that "ignorance of the law is no excuse" and cases that state that the law must be accessible and foreseeable.

There are various difficulties with the factual answer to the argument that the law was not accessible. The evidence accepted was of a very general knowledge of the application of English law to serious offending, the "fact that law ... exists", not of awareness of the details of what "rape" or "indecent assault" involved. The judges did not think the islanders needed to know the details of the offences, because someone could do it for them - but how much did that person need to be able to find out? Reliance on lawyers or other advisers to satisfy the obligation to educate or inform the populace about the content of law assumes that the advisers are able to discover the law's content. Some of the evidence described in the judgments suggests they might have had difficulty doing that.

Access to legal advice in general is not sufficient; the legal advisers themselves need to be able to ascertain the law. If a Pitcairn islander had asked what in the 1970s or 1980s what law applied to non-consensual sexual connection with a woman over 16, it is not clear what answer they would receive. Correspondence between the British High Commission in Wellington and the Pitcairn Magistrate in 1965 indicated that "if any male person should have carnal knowledge of a female child under the age of 12 years, that male person would be liable to be prosecuted under the English law of rape". ${ }^{48}$ It is not clear from this advice whether the writer thought English law of rape applied to girls over 12 in certain circumstances. In 1997 a Pitcairn Government Adviser thought it did: his view was that British law applied to carnal knowledge of a girl under 12 and island law to a girl between 12 and 16, but added "Pitcairn law does not cover rape - this comes under British law, punishable with up to life imprisonment". ${ }^{49}$ Further evidence of confusion emerged in the crossexamination of Paul Treadwell, the Pitcairn legal adviser at the time when the decision was made to prosecute the islanders. At one stage, he had expressed the view that the only law applicable to

$\begin{array}{ll}46 & R v \text { Christian (PISC), ibid, para } 107 . \\ 47 & R v \text { Christian (PISC), ibid, para } 155 . \\ 48 & R v \text { Christian (PISC), ibid, para } 102 . \\ 49 & R \vee \text { Christian (PISC), ibid, para } 104 .\end{array}$ 
sexual assault on Pitcairn was the local carnal knowledge offence, section $88 .^{50}$ These conflicting statements suggest that the lawyers who might have advised Pitcairn residents or officials were themselves uncertain about what law applied.

A recent English case held that technically a rule may be enforceable in domestic law immediately upon promulgation, but added that the situation may be different where the lawyers advising clients were not just unaware of the law change, they could not reasonably have been expected to have known of it. ${ }^{51}$ A new Act changed the rules governing appeals by asylum seekers with immediate effect, but copies of the Act were not made available for another three weeks. An asylum seeker argued that the new Act was not yet enforceable. Lord Phillips MR rejected this, saying "[i]t is beyond argument that an Act of Parliament takes legal effect on the giving of the royal assent, irrespective of publication." There was no reason in principle why the rules should not be enforced but whether they should be enforced depended on whether the lawyers involved were actually and reasonably unaware of the rule changes. If reasonable ignorance of law on the part of the lawyer is a reason why enforcement is unfair, the uncertain content of Pitcairn law suggests that access to legal advice was not enough to make up for the lack of publication.

The reason why the precise advice the islanders might have received is not the subject of judicial analysis is that the courts did not think precise advice was required. What convinced the Supreme Court that the law was ascertainable was that the islanders knew that law in general existed, that there was criminal law on Pitcairn, and that offenders would be punished. This was bolstered by a strict moral code. These findings do not mean, however, that islanders had adequate notice about what amounted in law to serious offending and of what offences came under the SOA. The court's argument begs the question: did this amount to knowledge of the relevant criminal law? Christian does not demand express awareness of the content of the law but it does not quantify the level of awareness that is needed.

\section{The argument based on knowledge of wrongfulness}

The Pitcairn Court of Appeal agreed with the Supreme Court that there was a requirement of accessibility, but it disagreed with the finding that information about the law was accessible for Pitcairn islanders. The reliance on access through others disturbed the Court of Appeal: ${ }^{52}$

We ... have some reservations as to whether accessibility in the way described could as a general

proposition be an adequate safeguard and necessarily always answer a challenge to any law which is

50 See Guest, above n 3, 16 .

$51 \quad R$ (on the application of $L$ and another) $v$ Secretary of State for the Home Department [2003] 1 WLR 1230 (CA), Lord Phillips MR.

$52 R v$ Christian (PICA), above n 4, para 108, Judgment of the Court. 
sought to be enforced. It seems to us that accessibility through a government agency may not always be sufficient...

The Court of Appeal did not explain in detail why this might not be sufficient but there are certainly several problems with the process. It is not stated by the Supreme Court whether islanders were able to request advice directly or whether they were expected to do so through an intermediary, nor is it clear whether island officials themselves had direct access to legal advice. There is certainly nothing to suggest that islanders had direct access to the legal adviser. What was available was not a real replacement for the access to solicitors that citizens resident in the home country would have. In addition, some of those to whom islanders' requests would be passed may have had an obligation to initiate prosecution if they became aware that an offence had been committed. Communications between islanders and the Commissioner or the Legal Adviser were unlikely to be covered by legal privilege. ${ }^{53}$ It is not really very likely, of course, that a person would seek advice about the definition of rape or sexual assault and then use that to decide whether to commit those offences. The main situation in which people rely on their legal advisers for information about whether their actions constitute an offence is regulatory offences. However, if the Supreme Court's finding was meant to be a general one, and not related merely to the offences of rape and indecent assault, this is a serious objection.

The judges who were not satisfied about accessibility of legal information upheld the convictions on other grounds. One approach is found in the advice of Lord Hope, in a section headed "the turning point". His point is that rape and indecent assault were not crimes created by the SOA. They were not new even when included in the Offences Against the Person Act 1861. The statutes built on the common law and, at the most, merely codified the definitions of the offences and prescribed penalties. ${ }^{54}$ The common law offences therefore still existed on Pitcairn. "No objection could have been taken on the ground of lack of promulgation if the prosecution of the appellants had been brought under the common law". ${ }^{55}$ This meant, he thought, that failure to publicise the later statutes was no bar to prosecution. One interpretation of this argument is that the earlier common law offence continued in existence, alongside the statutory offence, giving prosecutors a discretion which to use. There are multiple objections to such an argument, if this is what Lord Hope meant. It would not be confined to Pitcairn, nor to the crime of rape; any statutory scheme that "codified" criminal offences might be interpreted in the same way. It would make any amendments to statutory offences pointless, as the prosecution could revert to the "old" offence. Moreover, the same objections based on uncertainty would arise. There is not much difference between not knowing the details of the Sexual Offences Act and not knowing the details of the

53 Three Rivers District Council v Governor and Company of the Bank of England 48 [2005] 1 AC 610; [2004] 3 WLR 1274 para 28 (UKHL) Lord Scott.

$54 R v$ Christian (PC), above $\mathrm{n} 4$, para 84, Lord Hope.

$55 R v$ Christian (PC), above $\mathrm{n} 4$, para 85, Lord Hope. 
common law offences. It is more likely that what Lord Hope meant was that the common law offence had never required specific promulgation, and that no new requirement of publicity had arisen in 1861 or 1956 because no new offence had come into being. This ignores the point that the offence of rape was quite different in 1861, 1956 and then 2003. While the offences target the same wrong, they are defined differently, and as such cannot really be same to be the same offence.

The more important argument is that the nature of the offences that had been committed was such that difficulties of access to legal information did not really matter: the defendants either knew or should have known their activities were criminal and therefore there was no injustice in convicting them under the SOA. This is explained best in the judgment of the Pitcairn Court of Appeal.

The Pitcairn Court of Appeal started by emphasising that not all legal rules needed to be equally ascertainable. It quoted Fuller, who said that "to the extent that the law merely brings to explicit expression conceptions of right and wrong widely shared in the community, the need that enacted law be publicized clearly diminishes in importance". ${ }^{56}$ The court related ascertainability to the question of whether ignorance of the law should be an excuse and the possibility of unfairness where a person is convicted of an offence despite having no sensible access to the law. There is no unfairness if "the person in question knows the law", and it does not matter how they came to know "the law". ${ }^{57}$ So the question was redefined. It was not whether the SOA had been published but whether "the appellants can legitimately claim lack of knowledge that they were liable to prosecution under English law for the offences of rape, indecent assault, indecent assault on a woman and incest." 58 Relying on the Supreme Court's findings of fact the Court of Appeal concluded there was adequate awareness that conduct amounting to rape or indecent assault was unlawful, so the defendants could not reasonably claim ignorance. Ignorance of the penalties was not regarded as significant because they would have known that the penalty would be a "substantial term of imprisonment". 59

In the Privy Council, Lord Woolf considered both the physical accessibility issue, and the question of whether the islanders had sufficient knowledge of the law. He again relied on the Supreme Court's findings that there was access to information about criminal law and that islanders knew that rape was a serious offence, dealt with by English law: ${ }^{60}$

56 Lon Fuller The Morality of Law above n 9, quoted in $R v$ Christian (PICA), above $\mathrm{n} 4$, para 109, judgment of the Court.

$57 \quad R v$ Christian (PICA), above n4, para 110-111.

$58 \quad R v$ Christian (PICA), ibid, para 113.

$59 R v$ Christian (PICA), ibid, para 117.

$60 R v$ Christian (PC), above $\mathrm{n} 4$, para 44, Lord Woolf. 
To prosecute an individual for an offence of which he has no means of knowing the details is capable of being such a departure from the requirements of due process as to justify the prosecution being stayed. However, it is of the essence of an argument based on the lack of due process that the individual concerned would if the prosecution proceeded be treated unjustly and in this sense prejudiced. As in this case the Appellants suffered no prejudice in view of their state of knowledge an argument based on abuse of process would not be established.

On this approach to accessibility, the islanders must have known rape was a serious offence, and it did not matter that they did not and could not discover easily the details of the offence. They knew enough to know that their behaviour was not acceptable and would be punished if the authorities found out.

Although the arguments described above are presented differently, there are similarities between the two approaches to the argument that the law was uncertain and therefore unenforceable. Both make use of the idea that where there is knowledge that something is criminal in a broad sense, and possibly even if there is knowledge that it is "very wrong," there is no injustice in a conviction even for an uncertain or physically inaccessible law. A defence was denied to the defendants on Pitcairn because they must have known they were committing criminal offences. It did not matter they did not know what those offences were called or where the boundaries of criminal liability lay. The approach is captured in Lord Hope's comment that "[i]t is impossible to believe that the appellants were not aware that what they were doing was wrong". ${ }^{61}$

This analysis has suggested that, contrary to the findings of the various judges in the Pitcairn case, the law relating to sexual offences on Pitcairn was uncertain and had not been publicised. References to the appellants "knowing" that their behaviour was wrong suggests that decision to enforce that law, despite uncertainty and unascertainability was an application of the maxim that "those who skate on thin ice can hardly expect to find a sign which will denote the precise spot where [they] will fall in". ${ }^{62}$ This idea has been strongly criticised but, as the remainder of this article will show, it continues to influence courts when dealing with certain types of criminal offending. ${ }^{63}$ The rest of this article will look at other case law on uncertainty and consider whether it is ever acceptable to enforce uncertain criminal law and, if it is, what conditions must first be satisfied.

\section{WHEN WILL THE ENFORCEMENT OF UNCERTAIN CRIMINAL LAW BE PERMITTED?}

The Pitcairn case would have been a good opportunity for a discussion of why and when uncertain criminal law is enforceable. Unfortunately, this did not happen, because the various judges

\footnotetext{
$61 R v$ Christian (PC), above $\mathrm{n} 4$, para 55, Lord Hope.

$62 R v$ Knuller [1973] AC 435, 463 (HL) Lord Morris.

63 For a brief summary of the problems, see Ashworth, above n 14, 74-75.
} 
did not acknowledge that what they were doing was applying uncertain law. As a result, $R v$ Christian does not provide any way of identifying when uncertain criminal law will or will not be enforceable. This section will look at the other case law in an attempt to discern the criteria for enforcement and to consider whether the criteria in the case law are consistent with the purpose of the certainty rule.

A number of cases justify enforcement of uncertain or retrospective law on the basis that the law in question was not really uncertain nor retrospective because it was foreseeable or wholly consistent with the offence as previously defined.

One example of this kind of reasoning is found in a series of decisions about marital rape. In $R v$ $R$, decided in 1991, the Court of Appeal and House of Lords considered the ancient common law rule that a man could not be found guilty of raping his wife. They concluded that this so-called marital exception to the law of rape no longer existed, if it ever had, and so there was no objection to the appellant's conviction for the attempted rape of his wife. ${ }^{64}$ According to Lord Lane CJ, it was not necessary to wait for Parliament to remove the marital exception, and in fact it would be wrong to do so: "this is not the creation of a new offence, it is the removal of a common law fiction which has become anachronistic and offensive, and we consider that it is our duty having reached that conclusion to act upon it." ${ }^{65}$ On appeal, this passage was approved by Lord Keith. ${ }^{66}$ The reasoning of the English courts in $R v R$ did not dwell on the retrospectivity or uncertainty problem, but the decision was later challenged in the European Court of Human Rights on the basis that when the offence had been committed, the marital exception was valid law. The European Court of Human Rights rejected the challenge because the change in the law had been foreseeable or predictable: ${ }^{67}$

[T] his was an area in which the law had been subject to progressive development .... There were strong indications that still wider interpretation by the courts was probable. In particular, given the recognition by contemporary society of women's equality of status with men in marriage and outside it and their autonomy over their own bodies, the Commission is of the opinion that the adaptation in the application of the offence of rape was reasonably foreseeable to an applicant with appropriate legal advice.

$64 R v R$ (Rape: Marital Exemption) [1991] 1 AC 599 (UKCA and UKHL).

$65 R v R$ (Rape: Marital Exemption), ibid, 611 (UKCA) Lord Lane CJ.

$66 R \vee R$ (Rape: Marital Exemption), ibid, 623 (UKHL) Lord Keith.

67 CR v United Kingdom [1996] 1 FLR 434, para 59 (ECHR), Judge Ryssdal, President; Judges Gölcüklü, Russo, De Meyer, Martens, Bigi, Freeland, Jambrek, Lohmus. For further discussion of this case, see PR Ghandi and JA James "Marital Rape and Retrospectivity - the Human Rights Dimension at Strasbourg" (1997) 9 CFLQ 17 and C Osborne "Does the End Justify the Means? Retrospectivity, Article 7 and the Marital Rape Exemption" [1996] EHRLR 406 and ATH Smith "The Interpretation of Criminal Statutes" in J Finn and S Todd (eds) Law, Liberty, Legislation (Wellington, LexisNexis, 2008) 25. 
In the majority's view, far from it being a breach of the applicant's rights under the Convention, it was entirely consistent with the Convention to permit his prosecution and punishment. ${ }^{68}$ No distinction was made between legal change through judicial activism, as occurred in the marital rape cases, and legal change through the parliamentary process, which is what an observer is more likely to have predicted would eventually happen. If it would have happened eventually, there could be no complaint when it happened sooner rather than later and through a different mechanism of law reform.

The predictability of this law change was considered again in $R v C .{ }^{69}$ The rape in this case had taken place in 1970, and the appellant argued that at this time the law change was not predictable and therefore his prosecution was a breach of Convention rights. The Court of Appeal disagreed. If the appellant had sought legal advice, he would have been told that the law was developing and the immunity of husbands would eventually be removed. He would also have been warned that, even if he was not convicted of rape, non-consensual intercourse with his wife would involve the commission of some other offence, so that it was unwise to engage in such conduct anyway. ${ }^{70}$

The decisions on marital rape expected rather a lot from a hypothetical legal adviser explaining the law of sexual offences to a hypothetical client. The adviser needed to allow for the possibility that the change would arise through judicial activism rather than legislation, and thus have retrospective effect. ${ }^{71}$ However, the marital rape cases are not the only application of a wide approach to predictability. The applicant in $K-H W v$ Germany, then aged 20, had been a border guard in the German Democratic Republic. ${ }^{72}$ He shot and killed a man trying to escape from East Berlin. After reunification, he was convicted of intentional homicide. ${ }^{73}$ He appealed on the grounds that he was being convicted of something that was not an offence when it happened. Indeed, he had been congratulated rather than punished at the time. Under GDR law, it was technically an offence to use force to prevent anything other than the most serious offences, and escape over the border was not officially such an offence. ${ }^{74}$ However, the law in practice was that such homicides were not

$68 C R$ v United Kingdom, ibid, para 42.

$69 R \vee C[2004] 3$ All ER 1 (CA).

70 Ibid, para 19.

71 On this point, see Ghandi and James, above n 67.

72 K-H Wv Germany [2001] ECHR 229 (ECHR).

73 This was one of a number of trials of border guards for actions before reunification, not an isolated prosecution. The legislative background to the trials is explained in the case.

74 Under People's Police Act, s17(2), it was justified to use firearms to prevent the imminent commission or continuation of an offence which appeared to be a serious crime or to arrest a person strongly suspected of having committed a serious crime. Illegal border crossing was not listed in article 213(3) Criminal Code as a serious crime unless there was an aggravating feature such as the use of weapons or falsified papers. Other provisions of GDR law emphasised that human life should be preserved where possible, and the 
treated as criminal and indeed guards were ordered "not to permit border crossings, to arrest border violators or to annihilate them and to protect the State border at all costs ...". ${ }^{75}$ The applicant's argument was that this either overruled the written law or created a defence.

The European Court of Human Rights upheld the conviction. The Court acknowledged that there was a "contradiction between the principles laid down in the GDR's constitution and its legislation, on the one hand, which were very similar to those of a State governed by the rule of law, and the repressive practice of the border policing regime in the GDR and the orders issued to protect the border, on the other". ${ }^{76}$ Nonetheless, it was entirely predictable that shooting at those trying to leave the GDR was a criminal offence: the written law was accessible and clear. There was therefore no breach of certainty rules. The applicant was in "a difficult situation" but orders "could not justify firing on unarmed persons who were merely trying to leave the country". ${ }^{77}$

There are references to foreseeability and predictability in both the marital rape and border guard cases: is this the test for enforcement of uncertain law? What was said to be foreseeable in $C R$ $v$ United Kingdom and $R v C$ was how the offence of rape might be defined at some future point but it might be questioned just how foreseeable that actually was. The English Law Commission commented in 1990 that there was "a substantial body of law about the particular cases in which the exemption does not apply. The limits of this law are difficult to state with certainty. Much of it rests on first instance decisions which have never been comprehensively reviewed at appellate level". ${ }^{78}$ What legal advisers were expected to foresee was its future development and, furthermore, they were expected to allow for this to occur through case law rather than result from a well-publicised amendment to the Sexual Offences Act 1956. This is more complicated than saying that it was entirely predictable that non-consensual sexual intercourse was an offence. With the German border guards the source of uncertainty was, in part at least, the failure of a government to enforce existing law. Just as the longstanding failure to enforce law and order on Pitcairn did not result in any difficulty with later starting to enforce them, GDR citizens could not cite the gap between written law and law as it was practised as justification for a breach of the written laws.

Constitution included guarantees of human rights, including Article 30(1), "The person and liberty of every citizen of the German Democratic Republic are inviolable."

75 K-H Wv Germany, above n 72, para 17, Mr L Wildhaber, President.

76 K-H Wv Germany, ibid, para 63, Mr L Wildhaber, President.

$77 \mathrm{~K}-\mathrm{H} W v$ Germany, ibid, para 75, Mr L Wildhaber, President. The Berlin Regional Court, earlier in the history of the case, had suggested that "even for a private soldier, it should have been obvious that firing at an unarmed person infringed the duty of humanity and ... the applicant could have fired into the water without having to fear the consequences of disobeying orders, since it would have been impossible to observe the exact trajectory of the bullets under water" (para 17).

78 Law Commission for England and Wales Rape Within Marriage (Working Paper No 116, London, 1990) para 2.11. 
The importance of predictability can also be seen in cases where law was not enforced. Norris is one example. The United States government sought to extradite the appellant, a British national, from the United Kingdom. ${ }^{79}$ The indictment alleged, inter alia, a conspiracy to operate a pricefixing agreement during the 1990s. For extradition on this count to be available, this had to also be an offence under English as well as United States law. A district judge and Divisional Court held price-fixing was capable of amounting to the common law offence of conspiracy to defraud. The House of Lords allowed Norris's appeal: "there has never been a common law offence of pricefixing....[and] it would be wrong in principle for any court now to hold that there is or was, at the time of the events complained of ... such a common law offence". ${ }^{80}$ Legislation, judicial statements and ministerial statements at the time had conveyed a consistent message that price-fixing was not a criminal offence. "[I]t is not as if even an astute reader of legal articles in this area of law could have informed himself at the relevant time of the possibility of his price-fixing activities attracting criminal sanctions". ${ }^{81}$ The suggestion that this conduct was an offence at common law was made for the first time in a 2005 article. Norris's appeal succeeded.

A softer predictability test was applied in Rimmington. ${ }^{82}$ One of the appellants sent 538 postal packages to different recipients, all containing racially offensive material. He was charged with the common law offence of public nuisance. A well-accepted definition of this offence was cited by Lord Roger: ${ }^{83}$

A person is guilty of a public nuisance (also known as common nuisance), who (a) does an act not warranted by law, or (b) omits to discharge a legal duty, if the effect of the act or omission is to endanger the life, health, property, morals, or comfort of the public, or to obstruct the public in the exercise or enjoyment of rights common to all Her Majesty's subjects.

The prosecution relied on some recent cases that had enlarged the offence to cover obscene and nuisance telephone calls. The element of common injury was said to be present because of the cumulative effect of the calls and the nuisance was so widespread it should not be left to individual victims to bring proceedings. This enlargement of the offence was relevant, because Rimmington's communications had been with a number of separate individuals. Rimmington argued that the cases enlarging public nuisance had left the offence uncertain and unpredictable. The House of Lords agreed. Historically, public nuisance required common injury rather than injury to an individual or series of individuals. The recent cases had changed the nature of the offence and cut it "from its

79 Norris $v$ Government of the United States of America [2008] 1 AC 920 (HL).

80 Norris, ibid, para 52, Lord Bingham for the Court.

81 Norris, ibid, para 60, Lord Bingham for the Court.

$82 R v$ Rimmington [2006] 1 AC 459 (UKHL).

83 Rimmington, ibid, para 45, Lord Roger. Lord Roger indicated that the word "moral" should be removed from this definition. 
intellectual moorings." ${ }^{84}$ It therefore "lacked the clarity and precision which both the law and the [European] convention require". ${ }^{85}$ The conviction was quashed.

$R v$ Chilton is a New Zealand decision in which foreseeability was not relied on at all. ${ }^{86}$ The appellants failed to tell the Department of Social Welfare that they were living in a relationship in the nature of marriage. They were convicted of two offences under section 127 of the Social Security Act 1964: each had omitted to inform the Department of a matter affecting their own entitlement to benefit, and had also omitted to inform the Department of a matter affecting their partner's entitlement to benefit. The appellants argued that, as a result of the Court of Appeal's decision in Nicholson $v$ Department of Social Welfare ${ }^{87}$ they had no legal duty or obligation to inform the Department of anything that would affect their partner's benefit entitlement. The Crown conceded that this was the effect of Nicholson, but submitted that it was wrongly decided and should be overruled, with retrospective effect. The Court of Appeal concluded that Nicholson had been correctly decided. However, even if it had not been, it would not have been prepared to overrule it with retrospective effect anyway: "overruling Nicholson ... would have breached s10A of the Crimes Act and s26(1) of the BORA... As there was no positive obligation to disclose [at the time of the offence], the omission to do so cannot have constituted any offence under s 127 at the time of the omission. Case law as to the meaning of a statute is as much part of the law as the legislation itself. Thus, the principle against retroactivity would be engaged". ${ }^{88}$ While, because of the decision to uphold Nicholson, the point about retrospectivity is technically obiter, the court's view is strongly put. If we apply the test used in the marital rape cases, it may well been foreseeable that there would be a duty to inform the Department of Social Welfare of various matters, but there is no suggestion that this would have made a retrospective application of Nicholson valid.

A predictability test might be warranted if the sole purpose of the certainty rule is provision of fair notice about the reach of the criminal law. However, it is not, and a predictability test does not guarantee that there will be no injustice to individuals. Although the case law does not point this out, it might explain why predictability does not explain the outcome of all the cases. Some law that is said to be predictable must be on the far edge of what a person might foresee; the defendant in $K-H$ $W$ was actually expected to predict a change of political regime, not just a change in the law. The defendants in the marital rape cases were expected to foresee that courts would suddenly take the initiative and make a change to the law that many thought could only be made by Parliament. Rimmington is also puzzling. Had Rimmington sought legal advice, it is quite foreseeable he would

84 Rimmington, ibid, para 37, Lord Bingham.

85 Rimmington, ibid, para 37, Lord Bingham.

$86 R v$ Chilton [2006] 2 NZLR 341 (CA).

87 Nicholson v Department of Social Welfare [1999] 3 NZLR 50 (CA).

88 Chilton, ibid, para 109, Glazebrook J for the Court. 
have been told that public nuisance was in the process of being enlarged and it was predictable that it would next be extended to cover written communication as well as telephone calls. A point of distinction could be whether the conduct was criminal under some other description at the time when it occurred. In Christian, the Justice Ordinance offences could have been proved. In the marital rape cases, there would have been sufficient evidence for a conviction for an offence against the person or even indecent assault (which was not covered by the so-called marital exemption). Here again, though, it is difficult to exclude Rimmington from the same group as Christian, since there were alternative offences with which he could be charged. Assuming that the cases are correct and consistent with each other, and ignoring the official explanation, predictability or foreseeability would not appear to be the whole answer. Why was it unfair in some way to convict Rimmington but not to convict the men accused of raping their wives?

Is the seriousness of the offence a factor as well? The offending in the marital rape cases, $K-H \mathrm{~W}$ $\checkmark$ Germany and Christian, was clearly more serious than that in Rimmington, Norris and Chilton. They involved serious sexual offences and intentional invasions of another person's sexual autonomy. $K-H W v$ Germany was a homicide. There were "real" victims of these offences. While some would regard price-fixing as a serious offence - if it was not so regarded, the United States would not have tried to extradite Norris - it is an economic crime rather than a crime against the person. Chilton is another where the offence involves loss to the state rather than physical harm to a victim. However, this point of difference may not by itself be enough to distinguish Rimmington. Although his campaign did not involve the same degree of injury to others as rape and indecent assault, it was certainly deliberate and aimed to hurt the recipients of letters. There is one other difference that might help to separate Rimmington from the cases where uncertain law was permitted. One issue in the case (although this related to a conjoined appeal) was whether public nuisance had a fault element and if so what it was. The court held that a defendant was responsible for a nuisance which he know or ought to have known would arise as a result of his actions or omissions. ${ }^{89}$ This is a negligence or objective recklessness test. The offences in the marital rape cases and Christian had a subjective fault requirement, either intent (in the case of attempted rape) or recklessness (the mens rea for rape). A reasonable belief in the other's consent would have been a defence. A conviction required proof of fault. It may be this, rather than whether it was a "serious" offence, that allows the cases to be distinguished.

This review of the case law has shown that a variety of different factors are potentially significant. They include predictability, whether there is a fault element in the offence concerned, whether that requires proof of an intentional invasion of another's bodily integrity, and whether its development is consistent with its intellectual foundations. Not one of these seems to be decisive on its own. The answer to the question posed earlier in this section about where the line between

89 Rimmington, above n 82, para 39, Lord Bingham. 
enforceable and unenforceable uncertain law appears to lie is a combination of factors, a matrix rather than a bright line.

The next question is whether a test of this kind would be consistent with the reason for requiring certainty of criminal law in the first place.

The starting point is whether the modified certainty requirement will ensure that any given rule is sufficiently known or certain to be capable of directing behaviour. All this aspect of certainty needs is that the rule is clear enough or notorious enough to convey the message "do not do X" or "you must do Y". The case law indicates that, where law is concerned with the truly criminal, the need to publicise it or ensure it is certain is not so great. Citizens might be expected to adhere to common moral standards of behaviour and avoid any questionable behaviour, whether it is legally proscribed or not. Fuller wrote that, "to the extent that the law merely brings to explicit expression conceptions of right and wrong widely shared in the community, the need that enacted law be publicised and clearly stated diminishes in importance". ${ }^{90}$ Even without accepting some doctrines of natural law, this point has resonance. Where the central content of a rule is less easily predicted, because it does not involve behaviour widely considered as wrong or where a rule makes an omission criminal, a greater degree of certainty and publicity is needed in order for that rule to have any opportunity of directing or changing behaviour. The difference in treatment between truly criminal and strict liability or regulatory offences can therefore be explained. What makes Rimmington different, and possibly Norris as well, is that there was no guarantee someone convicted would be at fault.

Does the modified test also ensure that there is no injustice in the enforcement of the uncertain rule? One of the features that was common to all the cases in which uncertain law was upheld was that they involved criminal offences with a subjective mens rea requirement. This excludes one possibility of injustice: if individual justice is one reason for requiring certainty, provided mens rea was present there is no practical or moral difference between defendants who did have access to legal advice and statutes and those who did not. It is not normal for a person to consult their copy of the Crimes Act 1961 before going out, just to check that what they are planning to do is not criminal. It is possible that this requirement is based on the definition of the offence. If Rimmington is correct, it suggests that the question is not whether this particular person was at fault but whether it was possible for a person who was not at fault to be convicted if the statute was enforced. This would lead to a blanket refusal to enforce uncertain offences that were strict or absolute liability. It is also a more workable test given that claims of an abuse of process can be made pre-trial as well as part of an appeal against conviction.

90 Fuller, above n 9, 92. 


\section{CONCLUSION: A NEW PERSPECTIVE ON THE ENFORCEMENT OF UNCERTAIN CRIMINAL LAW}

This article has argued that the reasons given for upholding the convictions in Christian were partly wrong and also incomplete. The courts were correct in their view that some uncertain criminal law is enforceable but because they did not state explicitly that this was a case in which the law was uncertain, they failed to address the question of which uncertain law should be enforced and which should not. However, Christian and other case law on uncertainty contains some clues to the answer to this question.

Returning to the principles that this article started with, the version of the certainty principle as developed through the case law can now be stated more precisely. The common law version of the rule was described by Lord Diplock as requiring that "a citizen, before committing himself to any course of action, should be able to know in advance what are the legal consequences that will flow from it". ${ }^{91}$ In the criminal law context, this might now be better stated as a requirement that the citizen "should be able to find out, with the help of a legal adviser, whether it is predictable that a proposed course of action will be regarded as truly criminal, either now or in the future." If they cannot, and they were not at fault in any way (or possibly if there is no fault element in the offence itself), there may be a defence based on the unascertainability or uncertainty of the law. To decide whether this test is satisfied, we need to look at the elements of the offence, at whether its existence or latest incarnation was predictable, and, in some cases, at whether the accused person was themselves at fault. ${ }^{92}$ There are some objections to this modified certainty test. In this final section, the most obvious objections will be outlined, together with a preliminary response to them.

The first problem is that it provides no incentives for better government practice. If the normal result when an uncertain rule was relied on in a prosecution was that the prosecution would fail, this would be a powerful reason to ensure that law was clear and never applied retrospectively. The realist approach found in the case law discussed above prioritises the prosecution and punishment of the blameworthy over censure of overzealous prosecution policies. The response to this complaint is that a balance has to be found between the competing interests. The modified certainty test allows compromise between two competing sets of values, the fidelity to rule of law on the one hand, and the protection of the community from those who commit crime on the other: ${ }^{93}$

91 Black-Clawson International Ltd v Papierwerke Waldhof-Aschaffenberg AG, above n 8, 638, Lord Diplock.

92 As mentioned earlier, it is unclear whether the test recognises a defence of reasonable ignorance, is the basis of the discretion to stay proceedings where there is an abuse of process, or is an application of general constitutional principles, but this does not seem to make any substantial difference.

93 Greg Taylor "Retrospective Criminal Punishment under the German and Australian Constitutions" (2000) 23 UNSW LJ 196, 231. 
[A]ny prohibition on retrospective laws will, in certain cases, contradict the demand of substantive justice. This is due to the fact that the prohibition on retrospective laws will prevent some people from being prosecuted for offences not because they are morally free of blame, but because the legal system was not properly set up when they did what they did. There is thus a tension between the ideal of fidelity to law and the need to prosecute those who have committed what everyone agrees are extremely wicked acts.

In cases such as Christian, and the marital rape and border guard cases, this tension is resolved in favour of substantive justice, because of the seriousness of the crimes committed. Applying retrospective or uncertain laws is assumed to be the lesser evil and that is not necessarily an unreasonable assumption.

Rejection of this modified test would mean treating all uncertain criminal law the same. The difficulty here is that certainty is a question of degree - as is "ignorance". Not all prosecutors who rely on law that turns out to be uncertain are acting arbitrarily or unjustly. The line between enough certainty and not enough is not a bright line. This would be an objection to any decision rule that tries to deal with certainty - it is not a clear enough concept to be the subject of a precise rule and so the rule could always be criticised for drawing the line in the wrong place. How much detail is needed in someone's mind before you can say that they are no longer ignorant of a rule? The judgment that the Pitcairn islanders knew enough to be accountable assumes that a very rough sense of the law is enough, at least for serious crimes. The consequences of requiring complete certainty might be a rigidity of legal standards that became itself a source of injustice.

The next major objection to the modified certainty test is that it mixes up law and morality. Requiring only a very rough sense of the rules can also lead to the suspicion that what a person is aware of is not that a particular act is a crime but that it is wrong. This point is capable of lengthy discussion and cannot be resolved here, but the facts of the cases outlined in this article suggest a practical rather than theoretical response. Where rough and ready criminal definitions coincide with common morality, as with rape, murder and indecent assault, the average person is unlikely to clearly distinguish between the two. If it is forensically impossible to determine whether someone (a) thought something was morally wrong but not criminal, (b) thought something was both morally wrong and criminal and (c) thought something was criminal but was not morally wrong, perhaps the distinction is too fine to be of practical use.

A related issue is that, in saying that a rough idea of "the law" is enough and the requirements are at their most relaxed in the case of seriously criminal/immoral conduct, is that it assumes we have community-wide norms about what behaviour is acceptable or not: as has been seen, these norms play an important role in deciding whether someone had or should have had sufficient knowledge of "the law". In some of the cases outlined in this article the acceptance of those norms by the community group to which the accused belonged was in doubt. This is not a question of certainty as such but it may be an independent explanation for some of the unease that surrounds the decisions in Christian and also the border guard cases. 
Antony Duff points out that responsibility involves being answerable, and that means being answerable TO someone: ${ }^{94}$

If I give a bad lecture, there are various people who could hold me answerable: who could call on me to explain, to excuse, or to accept criticism for my failure. I am answerable to the students who must sit through the lecture; to my colleagues; to my university. But if some passing stranger heard about the lecture and tried to call me to account, I could properly reply that it was none of her business; she lacks the standing to hold me answerable for this lecture. In responding thus, I do not seek to explain, justify, or excuse my conduct. I simply refuse to answer for it to her.

Applying this to the law, Duff continues: ${ }^{95}$

The court speaks with the voice of the law, on behalf of the political community whose law it is. It calls her to answer, in this forum, to her fellow citizens for her alleged breach of their laws - which are also her laws. A further condition of criminal responsibility (and a further precondition of criminal liability) would then be that the court which tries the defendant must have the authority to call her to account, on behalf of a citizen body to whom she is answerable.

Where a court is constituted differently from one that might have been predicted at the time when the offending occurred, or where answerability to this court could not have been predicted at all, the danger of unfairness is all too present. It may be lingering doubts about this, rather than concerns about uncertainty as such that casts a shadow over decisions such as $K-W H v$ Germany. This is also why the conviction in the marital rape cases are more problematic where the rape was "historic". Political and social communities have time as well as physical dimensions and the community to which a husband might have belonged in the 1970s may not have shared the moral assumptions of the 1990s. The degree to which these concerns are of practical relevance to Pitcairn is unclear because there was never a formal defence based on difference of culture, but, if Pitcairn truly did have a different culture from England or New Zealand, that makes it much harder to draw the "should have known" conclusion. ${ }^{96}$

At one level the result of the Pitcairn case is surprising and alarming: the Pitcairn defendants did not know and could not have known the details of the offences of which they were convicted. It would, no doubt, have been a huge surprise to find themselves facing not the local Magistrate but a New Zealand judge, and facing a potentially massive prison sentence if convicted. Whether they were British in any meaningful sense was doubted, and the differences between their society and

94 RA Duff "Law, Language and Community: Some Preconditions of Criminal Liability" (1998) 18 Oxford Journal of Legal Studies 189, 195.

95 Duff, above n 94, 196.

96 On this point, see Guest, above $\mathrm{n} 3$ and Helen Power "Pitcairn Island: Sexual Offending, Cultural Difference and Ignorance of the Law" [2007] Criminal LR 609. 
that of the societies that trained and supplied the judges who heard their case and the lawyers who defended them were substantial. At the same time, the outcome also makes sense: how could anyone deny that they knew it was not just immoral but criminal to rape and sexually assault girls as young as 12 ? To say that their lack of knowledge meant they could not be convicted might be seen as the final injustice for their victims.

To return to the idea of an abuse of process with which the article began, courts are engaged in a difficult balancing act rather than applying a strict rule: ${ }^{97}$

If the court always refuses to stay such proceedings, the perception will be that the court condones criminal conduct and malpractice by law enforcement agencies. That would undermine public confidence in the criminal justice system and bring it into disrepute. On the other hand, if the court were always to stay proceedings in such cases, it would incur the reproach that it is failing to protect the public from serious crime. The weaknesses of both extreme positions leaves only one principled solution. The court has a discretion: it has to perform a balancing exercise.

Government inaction allowed the young women of Pitcairn to be assaulted in the first place and now the argument was that it prevented any retribution against their attackers. That would be a much greater injustice than conviction of the islanders for an offence which they knew, at some level, existed, and that had a subjective fault element. Certainty is an important principle rather than an inflexible requirement. On occasion other principles will and should take precedence. 